\title{
The modern rule of releases
}

\author{
Derek Whayman ${ }^{\star \dagger}$ \\ Newcastle University, Newcastle, UK \\ *Author e-mail: derek.whayman@newcastle.ac.uk
}

(Accepted 2 March 2021)

\begin{abstract}
This paper considers the history and nature of the 'modern rule of releases', concerning compromises to settle or preclude litigation. The rule holds that only matters the parties had contemplated as well as what they intended to release will in fact be released, even if the compromise has been made in the most general terms. Thus the rule is engaged when the releasor executes a general release but does not appreciate the existence of some of the claims the words used purport to release. This paper shows how the rule is a confusion of different conceptual bases and lines of authority and was created by accidentally muddling them together. It argues that, despite this, it successfully straddles both bases, functions well conceptually and serves a vital role.
\end{abstract}

Keywords: contact; compromises; releases; mistake; equity; interpretation

\section{Introduction}

This paper concerns the approach the courts take to releases, or, equivalently, compromises, where parties agree to settle or preclude litigation and execute a contract recording that compromise agreement. The twolimbed 'modern rule of releases' is that only matters the parties had subjectively contemplated (or, equivalently, realised or knew) they were releasing as well as what they purported to intend to release (determined from the interpretation of the releasing instrument) will in fact be released. This is even if the compromise has been made in the most general terms, professing to include every possible claim. Indeed this is where the rule bites, where one releases a class of claims using general words not appreciating the existence of some claims in that class. This jurisdiction has traditionally been regarded as an equitable one. However, in the leading English case, Bank of Credit and Commerce International SA v Ali, it was restated as an instance of common law contractual interpretation where no special equitable rules applied. ${ }^{1}$

There are two significant movements in contract law that challenge this understanding. First, Ali was decided during the ascendancy of Lord Hoffmann's expansive doctrine of objective contractual interpretation, when it was subsuming other doctrines of contract law. There has been a significant retrenchment of this movement, ${ }^{2}$ seen particularly in the cases of Arnold $v$ Britton ${ }^{3}$ and Marks and Spencer plc $v$ BNP Paribas Securities Services Trust Co (Jersey) Ltd. ${ }^{4}$ If interpretation is not so accommodating, this will have consequences for the rule of releases, particularly its contemplation limb, which features subjective elements that are hard, if not impossible, to fit into objective interpretation.

\footnotetext{
${ }^{\dagger}$ I would like to thank Dr David Gibbs-Kneller and the anonymous reviewers for their helpful feedback. All errors, of course, remain my own.

${ }^{1}$ [2001] UKHL 8, [2002] 1 AC 251.

${ }^{2}$ Lord Sumption 'A question of taste: the Supreme Court and the interpretation of contracts' (2017) 17(2) Oxford University Commonwealth Law Journal 301 at 313; cf D McLauchlan 'A sea change in the law of contract interpretation' (2019) 50 Victoria University of Wellington Law Review 657.

${ }^{3}$ [2015] UKSC 36, [2015] AC 1619 (on interpretation).

${ }^{4}$ [2015] UKSC 72, [2016] AC 742 (on implied terms).

(C) The Author(s), 2021. Published by Cambridge University Press on behalf of The Society of Legal Scholars. This is an Open Access article, distributed under the terms of the Creative Commons Attribution licence (http://creativecommons.org/licenses/by/4.0/), which permits unrestricted re-use, distribution, and reproduction in any medium, provided the original work is properly cited.
} 
Secondly, the wider context is the reform of some of the last conceptually uncertain doctrines of the law of contract in the last two decades. Ali was decided in 2001. Great Peace Shipping Ltd $v$ Tsavliris Salvage (International) Ltd (The Great Peace), rejecting the existence of a separate equitable doctrine of rescission for common mistake, was decided in 2002. ${ }^{5}$ In FSHC Group Holdings Ltd v GLAS Trust Corp Ltd ('Four Seasons'), decided in 2019, the Court of Appeal refined and restated the law of common mistake rectification, and offered various obiter dicta concerning unilateral mistake rectification and the role of subjectivism in contract. ${ }^{6}$ These doctrines represent in part the modern end state, after its retreat, of the old equitable jurisdiction over unfair contracts. The similarity is clear: the modern rule of releases is close to the doctrine of mistake because it is engaged when the parties do not appreciate all their rights and are thus mistaken. The question is whether the modern rule of releases will also be drawn back in line with this movement.

Given all this, and the paucity of literature on releases - it is described as 'an ancient and shadowy jurisdiction' in Meagher, Gummow and Lehane's Equity: Doctrines \& Remedies ${ }^{7}$ - it is high time for a reconsideration of the doctrine. This is one part of the law where the need for certainty and finality is paramount. The parties, having compromised uncertain claims, ought not to be afflicted by uncertainty thereafter. It would defeat the very point of compromising. Yet while Ali may have been on firm foundations when it was decided in 2001, it certainly is not now.

This paper has two functions. Neither is to challenge the aforementioned movements in the law of contract, but to examine the rule of releases with this background in mind. Its first function is to illuminate the convoluted origins and development of the rule of releases and its first vulnerability. Perhaps surprisingly, the intention limb is of common law origin, but was taken over by equity owing to the Court of Chancery's more flexible rules of evidence, and then given back to the courts of law in the nineteenth century. This limb developed independently from the contemplation limb, which came from a line of equitable cases for rescission for mistake as to what was being released based on the subjective knowledge of the mistaken party. The two, again somewhat surprisingly, were mixed together in the courts of common law.

This paper's second function is to examine the conceptual coherence of the rule of releases, bearing in mind the courts' desire to tidy, clarify and reform the doctrines of contract. Its two origins represent different substantive conceptual bases. The intention limb looks to uphold obligations consented to, and the contemplation limb looks to avoiding the contract altogether because the consent upon which it is founded is vitiated. Remarkably, owing to its particular and narrow purpose, it successfully straddles both bases. This makes it a rule sui generis which does not fit easily into any of the doctrinal compartments of the modern English law of contract, which is the second reason it is vulnerable. I argue that the rule is worth keeping given its utility and coherence. Alternatively, at a minimum, the law requires it in a reduced form where disclosure of the knowledge of the releasor's mistake by the other party is necessary if she is to rely on the release. Without this, there would be no remedy for cases of sharp practice.

\section{Two hard cases}

Before considering the development of the rule of releases and related doctrine, it is helpful to have some context to assist understanding it, and that means concrete facts. The instructive cases are the hard ones, where the facts are close to the boundary between different decisions. For release cases, this is where the release is general and where one or both parties were unaware of all the rights that such general words purpose to release. If the release is specific, ie only particular debts and claims are specified, that is conclusive for both interpretation and contemplation limbs of the rule and there is little controversy. Note that general releases with specific exceptions (for instance, exceptions for

\footnotetext{
${ }^{5}$ [2002] EWCA Civ 1407, [2003] QB 679.

${ }^{6}$ [2019] EWCA Civ 1361, [2020] Ch 365.

${ }^{7}$ JD Heydon et al Meagher, Gummow and Lehane's Equity: Doctrines \& Remedies (Sydney: LexisNexis Butterworths, 5th edn, 2014) para 14-090.
} 
unrelated personal injury claims seem to be commonplace) are still general for present purposes, because the difference between what the parties contemplated and what they purported to release is still a live issue.

To understand that boundary, one must understand the policy of the law. Although not stated baldly, it is clear enough from the speeches of the Law Lords in Ali and the many quotations cited with approval from the old cases. ${ }^{8}$ There is a tension between permitting the parties to release every possible claim in order to quiet matters, and depriving the releasor of rights she was unaware of by including them in that release. On the one hand, " $t$ ] he law cannot possibly decline to allow parties to contract that all and any claims, whether or not known, shall be released' ${ }^{9}$ and indeed it does not so decline. ${ }^{10}$ But on the other, 'the court will be very slow to infer that a party intended to surrender rights and claims of which he was unaware and could not have been aware. ${ }^{11}$ It also almost goes without saying that certainty is of paramount importance to the law of contract. The law must set the balance between these things.

This issue of balance will not only influence whether the court takes a broad or narrow approach to determining the question of what is included in the release. It will also influence the doctrinal compartment the rule of releases the courts might fit the rule into, because it is that compartment which determines or influences the requirements of the rule, its consequences and therefore that balance.

The first hard case is Bank of Credit and Commerce International SA v Ali itself. Ali concerned releases given by employees pursuant to terminating their employment by the now-notoriously corrupt and rotten Bank of Credit and Commerce International. At the time of executing the releases, it was thought that 'stigma damages', relating to the difficulty of finding new employment after having worked for such an institution, were not available for breach of contract. ${ }^{12}$ This proposition was later rejected by the House of Lords, ${ }^{13}$ and some of the ex-employees claimed this meant they had not released these claims despite having executed a general release, because neither side could have contemplated releasing what did not then exist.

The employees had signed ACAS COT-3 forms which recorded that:

The applicant ... agrees to accept the terms set out in the documents attached in full and final settlement of all or any claims whether under statute, common law or in equity of whatsoever nature that exist or may exist and, in particular, all or any claims rights or applications of whatsoever nature that the applicant has or may have or has made or could make in or to the industrial tribunal, except the applicant's rights under [the bank's] pension scheme. ${ }^{14}$

The majority interpreted the release to mean that the parties did not intend to release such claims. For them, it was not stretching interpretation too far to hold that it did not cover these uncontemplated claims. ${ }^{15}$ The release could be interpreted with the relevant context that the parties had contemplated only the uncontested claims for money in lieu of notice and redundancy pay. Consequently, they had intended to release only those liabilities.

Lord Hoffmann, alone, held that the release did indeed cover claims for stigma damages. ${ }^{16}$ Such claims were not of a sufficiently different character and it would strain the process of interpretation

\footnotetext{
${ }^{8}$ See also NH Andrews 'Mistaken settlement of disputable claims' (1989) Lloyd's Maritime and Commercial Law Quarterly 431.

${ }^{9}$ BCCI v Ali [2001] UKHL 8 at [9].

${ }^{10}$ Eg Moore $v$ Weston (1872) 25 LT 542.

${ }^{11}$ BCCI $v$ Ali, above n 9, at [10].

${ }^{12}$ On the authority of Addis v Gramophone Co Ltd [1909] AC 488; Withers v General Theatre Corpn [1933] 2 KB 536.

${ }^{13}$ Malik $v$ Bank of Credit and Commerce International SA [1998] AC 20.

${ }^{14}$ BCCI $v$ Ali, above n 9, at [3].

${ }^{15}$ Ibid, at [18]-[19] (Lord Bingham, with whom Lord Browne-Wilkinson agreed); at [35] (Lord Nicholls); at [86] (Lord Clyde).

${ }^{16}$ Ibid, at [73].
} 
too much to exclude them. ${ }^{17}$ The purpose of the release was specifically to deal with unknown quantities. It was not merely to pay off the uncontested claims, since there was additional consideration above and beyond their value. The additional consideration, some $£ 2,700$, had to be for something, and that something must have been any claims of which the parties were unaware, since there were no claims they were aware of at the time. ${ }^{18}$ The parties were buying peace.

One should note two more points made by the House of Lords before moving on. First, Lord Hoffmann thought the solution of requiring the drafter to produce an even stronger clause through an excess of verbiage in order to drive home the point that all, even uncontemplated, claims were covered would be 'overkill'. Instead, the use of 'common sense' to determine meaning was appropriate. ${ }^{19}$ The other Law Lords did not address this matter directly, but two tend towards the same opinion. Lord Nicholls said that the matter went beyond even 'widely drawn' language. ${ }^{20}$ Lord Clyde was confident that the short COT-3 formula was wide enough to handle all but 'remote' claims. ${ }^{21}$ We can, therefore, be fairly confident that no additional currency will be placed in the use of excessively long statements aimed to drive the point home. It is not clear from these statements whether expressly providing that uncontemplated liabilities are covered would be effective, but we return to this point shortly.

Secondly, the House did not rule on what it described as 'sharp practice' cases. ${ }^{22}$ In his leading speech, Lord Nicholls did not voice any obiter suggestions on this matter, expressly preferring to wait for such a case before making a decision. ${ }^{23}$ Lord Hoffmann went a little further, leaving open the possibility of a separate doctrine to deal with cases of sharp practice:

[O]ne could say, as the old Chancery judges did, that reliance upon such a release is against conscience when the beneficiary has been guilty of a suppressio veri or suggestio falsi. On a principle of law like this, I think it is legitimate to go back to authority, to Lord Keeper Henley in Salkeld v Vernon 1 Eden 64, 69, where he said: "no rule is better established than that every deed obtained on suggestio falsi, or suppressio veri, is an imposition in a court of conscience". ${ }^{24}$

[I]n my opinion the principle that a party to a general release cannot take advantage of a suggestio falsi or suppressio veri, in other words, of what would ordinarily be regarded as sharp practice, is sufficient to deal with any unfairness which may be caused by such releases. There is no need to try to fill a gap by giving them an artificial construction. ${ }^{25}$

Clearly, Ali was not such a case. Neither party had made a misrepresentation nor had suppressed the truth. Hospital Products Ltd $v$ United States Surgical Corporation, ${ }^{26}$ an Australian decision, supplies the relevant facts and is the second hard case. Hospital Products had set about cloning United States Surgical's medical stapling products. In order to build up market share while still developing their production capacity, Hospital Products started surreptitiously selling on United States Surgical's products disguised as their own. This was a breach of contract, from which damages due to lost sales naturally flowed. After the surreptitious activities had begun, the two sides concluded a general release in connection with the termination of their dealership agreement. The New South Wales court held that this did not cover the losses on the grounds that the parties clearly had not contemplated that the

\footnotetext{
${ }^{17}$ Ibid, at [60], [64]-[65].

${ }^{18}$ Ibid, at [40]. Chadwick LJ, in the court below, agreed: BCCI $v$ Ali [2000] 3 All ER 51 at [77].

${ }^{19}$ BCCI $v$ Ali, above n 9, at [38].

${ }^{20}$ Ibid, at [28].

${ }^{21}$ Ibid, at [86].

${ }^{22}$ Ibid, at [32].

${ }^{23}$ Ibid, at [32]-[33].

${ }^{24}$ Ibid, at [69].

${ }^{25}$ Ibid, at [71].

${ }^{26}$ (1984) 156 CLR 41. Note that the matter of the release was not appealed to the High Court, and was settled in the court below: [1982] 2 NSWLR 766.
} 
surreptitious activities would be covered by the release. As McLelland J noted, Hospital Products' activities were 'concealed' from United States Surgical. ${ }^{27}$ This suggests that a term expressly covering uncontemplated liabilities should not and would not be effective in such circumstances.

Even before considering the elements of the rule of releases and objective interpretation in detail, there is at least a nagging doubt that the results of both cases cannot be reliably reached purely through objective contractual interpretation. Indeed the Court of Appeal below in BCCI $v$ Ali unanimously considered that something more than mere interpretation was required to reach the conclusion that the release did not cover uncontemplated claims. ${ }^{28}$ Moreover, as Sheehan points out, Ali was materially identical to Bell $v$ Lever Brothers Ltd and accordingly the ex-employees of BCCI should have lost, since their mistake was not sufficiently fundamental to engage the doctrine of common mistake. ${ }^{29}$ On this basis, it is only the contemplation limb of the modern rule of releases that enabled the claimants to win in Ali and Hospital Products, whether it came from objective interpretation or that something more.

\section{Historical development}

The contemplation limb came from equity and consequently in this section we look at the history of the rule. This certainly throws light on the significance of the old cases. But such an approach is not only of antiquarian interest, as the Court of Appeal's judgment in Four Seasons, in the context of rectification, shows. ${ }^{30}$ An examination of the roots of the doctrine allows one to see more clearly its conceptual bases, justifications and how it applies, which in turn assists the assessment of the coherence of the rule and any potential reforms to it.

This means going beyond the studies in the leading cases. In BCCI $v$ Ali, the House of Lords reviewed much of the history of the release cases; the High Court of Australia did so in somewhat greater depth in the Australian leading case of Grant $v$ John Grant \& Sons Pty Ltd. ${ }^{31}$ What neither court did, and what is done here, is not only to push back further in time, but also to distinguish sharply the distinct lines of authority and identify the complex interplay between the courts of equity and the common law, which culminated in the merger of the two lines of authority, creating the modern rule of releases from two distinct conceptual bases.

\section{(a) Common law interpretation}

The earliest cases of releases were at common law and developed even before assumpsit had become the dominant form of action to turn to, let alone before the modern approach to consideration had settled, such was the importance of quieting disputed claims. ${ }^{32}$ The approach to interpretation in this era and even later would be characterised by the author of Wigmore on Evidence as stiff and inflexible. ${ }^{33}$ Releases of executory obligations could be made by parol, but releases of debt had to be made by deed in the seventeenth century. ${ }^{34}$ In Justice Windham's Case, the Court of King's Bench said in clear terms that a release would be construed, in effect, contra proferentem against the releasor, ${ }^{35}$ quite the opposite of the current approach. A general release was interpreted literally. For instance, in Rotheram $v$ Crawley, a release of 'all actions, duties, and amercements' successfully released a 'collaterall thing'

\footnotetext{
${ }^{27}$ [1982] 2 NSWLR 766 at 818.

${ }^{28}$ [2000] 3 All ER 51 at [25], [34] (Scott V-C), [75] (Chadwick LJ), [92] (Buxton LJ).

${ }^{29}$ [1932] AC 161; D Sheehan 'Unconscionability and mistake in the Court of Appeal' (2001) Journal of Business Law 107.

${ }^{30}$ [2019] EWCA Civ 1361.

${ }^{31}$ (1954) 91 CLR 112.

${ }^{32}$ AWB Simpson A History of the Common Law of Contract: The Rise of the Action of Assumpsit (Oxford: Clarendon, 2nd edn, 1987) at 174-177 (see generally pt II).

${ }^{33}$ Cited in BCCI $v A l i$, above $\mathrm{n} 9$, at [24].

${ }^{34}$ Fortescue v Brograve (1646) Style 8; Milward v Ingram (1675) 1 Mod 205; Milward v Ingram (1675) 1 Freem Ch 195; Milward v Ingram (1675) 2 Mod 43.

${ }^{35}(1588) 5$ Co Rep $7 \mathrm{a}$ at $7 \mathrm{~b}$.
} 
and Coke's argument that it ought to release only what was intended was rejected. 'Duty' was interpreted to mean all duties known to the law in $1592 .{ }^{36}$

But even the stiff common law of Tudor times had to bend to reality. Several cases held that a general release covered only pre-existing breaches of a covenant, not future breaches. ${ }^{37}$ For instance, in Trevil $v$ Ingram, it was held that a general release of 'all actions and demands, \&c' did not release future rents. ${ }^{38}$ That release also did not release a heriot (a mediaeval death duty), because it had not been a certain demand and was therefore a future duty, despite it pre-existing the release in some form.

This cut-off based on time and certainty is probably the smallest concession to contextualism possible. It is hard to see how releases could have functioned otherwise. Unlike in cases of contracts and conveyances - individual transactions - a commitment to really strict literalism would have made the coverage of general releases inordinately large. It would have made it impossible to contract with the releasor ever again, for every future obligation would have been released ex ante. The unique pressures produced by the particular circumstances of a release pushed the law forward here far ahead of the general adoption of a contextual approach in the twentieth century. This also shows the absolute need for this part of the rule of releases.

The important question is on what conceptual basis, and on what rule, was the contextual interpretation in these cases made? In Trevil $v$ Ingram, counsel for the claimant argued that since the defendant had not taken the steps that would have made him liable for the heriot, the parties knew it was uncertain and consequently could not have intended to include it. The claimant succeeded, but the reasoning in the judgment is limited to saying that the opinion of the whole court was that of the claimant's argument. ${ }^{39}$ However, the intention basis was emphatically affirmed less than two years later, in Knight $v$ Cole. Shower, for the claimant, succeeded where Coke had failed; he managed to persuade the Court of King's Bench that a general release ought to be constrained to what the parties intended despite the clear words of release of 'all actions, suits, and demands whatsoever'. ${ }^{40}$ This time a majority of the court (Eyres, Gregory and Dolbin JJ) expressly adopted the intention basis: 'the intent must guide us' ${ }^{41}$ Holt CJ did not, but he did not reject it either. Accordingly, Knight $v$ Cole is cited by John Grant (but not by BCCI $v$ Ali) as the foundation of this doctrine. ${ }^{42}$

The fundamental weakness of this doctrine was in the historic law of evidence. The parol evidence rule precluded adducing evidence to vary or contradict a written contract. There was also the rule that parties (and other interested persons) were not competent to testify, on the basis that they might be incentivised to lie. This restricted the range of evidence the courts could use to construe this intention. Consequently, the cases concerned documentary or circumstantial evidence rather than direct evidence of the parties' intentions. Hence the most significant concrete rule that emerged from this time was that the recitals to a release constrained any general words of release to the subject-matters of the recitals, ${ }^{43}$ though the conceptual basis remained intention. No doubt this would have reduced the impact of perjury and fraud (and one must note that the Statute of Frauds 1677, bearing the same objective, was passed in the same year as the decision in Trevil $v$ Ingram). The point is, however, that the procedural law determined much of the substantive law.

In addition, the conceptual reach of the rule of releases was still limited. None of the cases spoke of the background knowledge of the parties or what they had contemplated releasing, which are

\footnotetext{
${ }^{36}(1592)$ Cro Eliz 370 at 370; (1592) Owen 71 at 71.

${ }^{37}$ Hall v Kirby (1561) 2 Dyer 217b; Hoe's Case (1591) 5 Co Rep 70b. Cf Richmond $v$ Savill [1926] 2 KB 530 where the surrender of a lease relieved from only future obligations.

${ }^{38}$ (1677) 2 Mod 281 at 281.

${ }^{39}$ Ibid.

${ }^{40}(1691) 1$ Show KB 150 at 150, reporting his own arguments at length. Serjeant Levinz, for the defendant, produced a much shorter report: (1690) 3 Lev 273.

${ }^{41}(1691) 1$ Show KB 150 at 155 (Dolbin J); the 'intent was to release no more than what he had in his own right' (Eyres J); 'the original intent was but to release the five pounds legacy' (Gregory J).

${ }^{42}$ John Grant (1954) 91 CLR 112 at 123.

${ }^{43}$ Thorpe $v$ Thorpe (1701) 1 Ld Raym 662. See also eg Lindo v Lindo (1839) 1 Beav 496.
} 
uncontroversially elements of the present-day rule. ${ }^{44}$ This factor did not appear in a common law releases case until Lyall $v$ Edwards, in $1861 .{ }^{45}$ But it did appear in the eighteenth-century equity cases where rescission was claimed.

\section{(b) Equitable rescission}

During the formative years of the common law interpretation of releases, the Court of Chancery did not appear to have had much business in the interpretation of contracts. One must suspect that there would have been a successful demurrer for want of equity when a court of common law could offer an adequate remedy. For the interpretation of the scope of a release and the determination of the primary common law claim, the remedy sought would often have been damages or debt rather than rescission. Then the common law courts' remedy would have been adequate.

Cases contemporaneous with Knight $v$ Cole show different doctrines emerging from the Chancery's ancient wide, discretionary jurisdiction. Deeds could be set aside for suppressio veri as well as suggestio falsi, ${ }^{46}$ which Kerly described as 'a small survival of extensive powers once wielded by the Court'. ${ }^{47}$ Atiyah's view is that it was 'clear enough that in and around 1770 it was at least the established tradition in Chancery that a contract must basically be fair; or perhaps, to be more strictly accurate, that a grossly unfair contract was liable to be upset'. ${ }^{48}$ We see dicta such as equity 'relieves against bargains made under a misconception of rights ${ }^{39}$ and that:

The cases in which Equity interferes to set aside contracts are those in which either there has been mutual mistake or ignorance in both parties affecting the essence of the contracts, or a fact is known to one party and unknown to the other, and there is some fraud or surprise upon the ignorant party. ${ }^{50}$

The wide jurisdiction was not to survive for much longer. By Farewell v Coker (1726), the Chancery had begun to apply more defined rules. The case concerned a complex post-inheritance resettlement of lands within a family. Susannah Farewell did not realise she had inherited certain reversions in land and entered into an agreement with her brother Robert Coker that included a very clear general release. ${ }^{51}$ Two issues were directed for trial: first, whether she did not know of her interest in the reversion; and secondly, whether she intended to pass it by the release. ${ }^{52}$ This tells us that matters contemplated, as well as intended, were part of this equitable doctrine. The word 'contemplation' itself appeared soon after, in Ramsden $v$ Hylton (1751)..$^{53}$

Awareness, knowledge, or contemplation, however it is expressed, is clearly applicable to other doctrines that emerged from the old general jurisdiction. There was once an ill-defined jurisdiction to set a contract aside for equitable mistake as to the facts, confirmed by the House of Lords in Cooper $v$ Phibbs. ${ }^{54}$ If the

\footnotetext{
${ }^{44}$ See also Lampon $v$ Corke (1822) 5 B \& Ald 606; Payler v Homersham (1815) 4 M \& S 423. These cases spoke of intention or what the parties 'meant'.

${ }^{45}(1861) 6$ H \& N 337.

${ }^{46}$ Eg Broderick v Broderick (1713) 1 P Wms 239; Salkeld v Vernon (1758) 1 Eden 64.

${ }^{47}$ DM Kerly An Historical Sketch of the Equitable Jurisdiction of the Court of Chancery (Cambridge: Cambridge University Press, 1890) p 246.

${ }^{48}$ PS Atiyah The Rise and Fall of Freedom of Contract (Oxford: Clarendon, 1979) p 147. Atiyah also noted the unpredictability of the Chancery's decisions of that time.

${ }^{49}$ Bingham v Bingham (1748) 1 Ves Sen 126.

${ }^{50}$ Earl Beauchamp $v$ Winn (1873) 6 LR HL 223 at 233. This is a remarkably late appearance of such a broad proposition.

${ }^{51}$ Reported in Marquis Cholmondeley $v$ Lord Clinton (1817) 2 Mer 171 at 354.

${ }^{52}$ Ibid, at 355. See also Farewell $v$ Coker (1726) 2 Jac \& W 192.

${ }^{53}$ (1751) 2 Ves Sen 304 at 310; see also Cole v Gibson (1750) 1 Ves Sen 503 at 507 ('knowing'), cited in Ramsden; also Pusey $v$ Desbouverie (1734) $3 \mathrm{P}$ Wms 315.

${ }^{54}$ (1867) 2 LR HL 149; Solle v Butcher [1950] 1 KB 671. See H Beale Chitty on Contracts (London: Sweet \& Maxwell, 33rd edn, 2018) para 6-024: 'It is not easy to discern the basis for relief.
} 
parties were unaware of the extent of the claims they were purportedly releasing with general words, that is undoubtedly a common mistake of the kind relevant to this jurisdiction.

Yet all of these matters concerned the setting aside of contracts. It is one thing to limit the agreement via a process of interpretation of the intentions of the parties. It is quite another to avoid the contract altogether on the ground there is a mistake, a vitiating factor, that impairs that consent. In the former case, there is sufficient unvitiated consent to releasing at least something, which is why reading down a general clause but upholding the contract is appropriate. In the latter, the parties' consent is impaired to a greater extent, meaning that they would not have contracted on the basis they did had they realised. The two matters have different conceptual bases and different remedies.

\section{(c) Equitable interpretation}

We do see contemporaneous equitable interpretation cases. They are, unfortunately, elusive. If one attempts to trace back from the leading cases of Ali and Grant or the old treatises on equity, ${ }^{55}$ no such cases are found. Instead, many rescission cases are cited, including Cole $v$ Gibson ${ }^{56}$ and Ramsden $v$ Hylton, ${ }^{57}$ which state, somewhat delphically, that equity would 'restrain' releases to matters contemplated by the parties.

It is tolerably clear, however, that the Chancery took such interpretation cases. Pollock wrote in his Principles of Contract that there was in both:

courts of law and equity [a] power to put a restricted construction on general words when it appears on the face of the instrument that it cannot have been the real intention of the parties that they should be taken in their apparent general sense. Courts of equity went farther, and did the like if the same conviction could be arrived at by evidence external to the instrument. ${ }^{58}$

Therein lies the secret of the utility of the equitable jurisdiction for interpreting releases. It was not related to the lines of authority that became mistake, rectification, undue influence and unconscionable bargains, namely what is left of equity's jurisdiction over contracts. It was the (relatively speaking) superior rules of evidence at the Chancery. The parol evidence rule did not exist in equity. While the Chancery did not then take live evidence, it did at least take interrogatories (depositions) of the parties' sworn evidence, ${ }^{59}$ which would have enabled the admission of at least something to colour the interpretation of the words of a written document. Equity's auxiliary jurisdiction then provided a remedy where that at common law was inadequate.

Yet most of these cases are apparently not reported. Instead, remarkably, the equitable rules of evidence - and thus a distinct equitable doctrine of interpretation of at least a kind - were applied by the common law courts at the time, long before the end of the split court system that came with the Judicature Acts of 1873 and 1875.

\footnotetext{
${ }^{55}$ Those with sufficient detail are: J Story Commentaries on Equity Jurisprudence, vol 1 (London: A Maxwell, 2nd edn, 1839) $\$$ 120-121; H Ballow and J Fonblanque A Treatise of Equity, vol 1 (London: W Clarke \& Sons, 4th edn, 1812) pp 440-443.

${ }^{56}(1750) 1$ Ves Sen 503 at 507.

${ }^{57}(1751) 2$ Ves Sen 304 at 310.

${ }^{58} \mathrm{~F}$ Pollock Principles of Contract: A Treatise on the General Principles Concerning the Validity of Agreements in the Law of England (London: Stevens \& Sons, 9th edn, 1921) p 544.

${ }^{59} \mathrm{~W}$ Blackstone Commentaries on the Laws of England, Volume 3 (Oxford: Clarendon, 1765-1769) pp $373,438$. Cross-examination in relation to new testimony was therefore impossible. Cases were occasionally referred to law to take live evidence, a very slow and cumbersome process. See eg Coker v Farewell (1729), reported in Dillon v Parker (1818) 1 Swan 359 at 390; Coker v Farewell (1729) 2 P Wms 563; Coker v Farewell (1729) 1 Swanst 403; Farewell v Coker (1728) 2 $\mathrm{P}$ Wms 460; Farewell $v$ Coker (1726), reported in Marquis Cholmondeley $v$ Lord Clinton (1817) 2 Mer 171 at 354; Farewell v Coker (1726) 2 Jac \& W 192.
} 


\section{(d) Equitable plea and replication in the common law courts}

The claim that equity and trusts were unknown to the common law courts, which acted as though such rights did not exist, ${ }^{60}$ is a proposition that has a nice classical ring to it, but one which ignores the messy reality of the split court system in the eighteenth and nineteenth centuries. It is certainly true that one had to start a suit in the Chancery where the underlying right was equitable, and that one had to litigate an action entirely at law where there was no equitable component. But it does not follow from this that one had to go to the Chancery for a common law claim with an equitable defence or equitable defence and rebuttal to that defence (more properly, a 'plea' and 'replication' respectively) ${ }^{61}$ to a common law claim. More to the point, the cases bear this out.

Lionel Smith, with painstaking rigour, has demonstrated that the tracing cases of Scott $v$ Surman ${ }^{62}$ and Taylor $v$ Plumer, ${ }^{63}$ while decided in the Court of Common Pleas and Court of King's Bench respectively, were decided upon equitable trust principles. ${ }^{64}$ These were claims for money had and received and trover respectively. In these cases, assignees in bankruptcy had ostensibly acquired title to the property in dispute under the relevant bankruptcy statute. However, the courts held that the statute did not assign legal title to property to assignees in bankruptcy if it was subject to a trust. This meant that the assignee's common law claim in Taylor $v$ Plumer could be resisted and the relevant common law claim in Scott $v$ Surman against the assignee could succeed because of the extant trust interests - in actions in the common law courts. ${ }^{65}$

Smith argues that the law followed equity in determining the existence of the trust in order 'to prevent circularity', ${ }^{66}$ namely expensive and time-consuming trips back and forth between the courts of common law and the courts of equity. This to-ing and fro-ing is exactly what had happened in Farewell $v$ Coker. ${ }^{67}$ It is almost certainly the main justification, particularly at a time where the Court of Chancery was in decline, beset with delays and faced a huge backlog of causes. ${ }^{68}$ However, Smith did not identify the procedural mechanism, which can now be explored.

In the tracing cases, it was the equitable plea - that there was a traceable trust interest in the property such that the bankruptcy statute did not apply - that prevailed over the equitable replication that tracing was impossible on the facts. In the release cases, there was an equitable plea of release, followed by an equitable replication that the release was not good because the parties did not intend to release the contested claim, or had not contemplated releasing it. The procedure, and the justification, it is submitted, were the same.

Of the release cases, we see next Payler $v$ Homersham (1815). The judgment is extremely short, but Lord Ellenborough CJ, who had decided Taylor v Plumer earlier that year, called the rebuttal of the plea of release a 'replication', albeit without mentioning equity. ${ }^{69}$ Similarly, in the next case, Lampon $v$ Corke, counsel for defendant argued that equity ought not to be applied in a court of law, although the court did not comment on this submission. ${ }^{70}$ These cases are thus inconclusive

\footnotetext{
${ }^{60}$ Eg FW Maitland Equity: A Course of Lectures (J Brunyate, AH Chaytor and WJ Whittaker eds, Cambridge: Cambridge University Press, 2011) p 248: 'For of the trust a Court of Common Law would take no notice at all'.

${ }^{61}$ See J Mitford A Treatise on the Pleadings in Suits in the Court of Chancery (Dublin: Eliz Lynch, 2nd edn, 1789) p 391 $\left({ }^{*} 321\right)$.

${ }^{62}(1742)$ Willes 400.

${ }^{63}$ (1815) 3 M \& S 562. There were others: Golightly v Reynolds (1772) Lofft 88 (trover); Gladstone v Hadwen (1813) 1 M \& S 517 (trover).

${ }^{64}$ LD Smith 'Tracing in Taylor v Plumer: equity in the court of King's Bench' (1995) Lloyd's Maritime and Commercial Law Quarterly 240; Trustee of the Property of FC Jones \& Sons v Jones [1997] Ch 159 at 169.

${ }^{65}$ Statute of Bankrupts 1623 (21 Jac 1 c 19) ss 10, 11; first in L'Apostre v Le Plaistrier (1708), reported in Copeman v Gallant

(1716) $1 \mathrm{P}$ Wms 314 at 406; then Copeman $v$ Gallant itself. The reasoning is not reported.

${ }^{66}$ Smith, above n 64, at 247.

${ }^{67}$ Above n 59.

${ }^{68}$ Sir J Baker An Introduction to English Legal History (Oxford: Oxford University Press, 5th edn, 2019) p 120.

${ }^{69}(1815) 4 \mathrm{M} \& \mathrm{~S} 423$ at 427.

${ }^{70}$ (1822) 5 B \& Ald 606. The court decided the matter on the basis of intention as construed from the deed and thus did not need to consider the matter of what the parties contemplated.
} 
of the question of whether equitable principles were being applied in the common law courts, but it is likely they were, given the foregoing.

However, in Phillips $v$ Clagett (1843), in the Court of Exchequer - two years after the abolition of the Exchequer's equity jurisdiction ${ }^{71}$ - Lord Abinger CB said it was the established practice for courts of law to apply equitable principles, particularly in release cases such as the present. ${ }^{72}$ Indeed, the jurisdiction to do so was soon after put on a statutory basis in the Common Law Procedure Act $1854 .^{73}$ Another contemporaneous development was Lord Denman's Act 1843, providing that the defendant could be examined as a witness in court. ${ }^{74}$ The County Courts Act $1846^{75}$ made all parties competent witnesses in inferior tribunals, and the Evidence Act $1851^{76}$ extended this to all courts of justice.

This brings us to Lyall $v$ Edwards (1861). ${ }^{77}$ Since this is the first case where all the prerequisites were in place, it is fair to say that this is where the modern rule of releases was born. All three judges made it clear that they were applying equitable principles in a common law court - which of course now had better powers to take evidence than ever before. The facts were fairly simple. Two colonial brokers entered into a composition (a compromise package) with their creditors, resolving to realise their assets, pay their debts in part, and from this they would be released of all liability. The release clause was prodigiously, tediously long and there can be no doubt the drafter 'meant business' in drafting it to cover absolutely everything. ${ }^{78}$ However, the claimants later discovered they had a claim not in debt, but in trover, for the conversion of 22 chests of indigo against the brokers, which they had not known of and had not claimed in the composition. The Court of Exchequer held that this was a good replication to the plea of release.

The court's reasoning concluded with the modern rule of releases. It is how the court got there that is crucial. Counsel for the claimants argued that courts of equity would 'admit collateral evidence that the release was not intended to apply to the cause of action mentioned in the declaration'. ${ }^{79} \mathrm{He}$ also submitted that the authorities showed that a release would only apply to what was contemplated, citing Farewell $v$ Coker and Cole $v$ Gibson. These submissions were accepted. Pollock CB required both limbs of the modern rule of releases, intention to release and knowledge of what was being released. Martin B asserted that Farewell $v$ Coker was authority for the proposition that equity would 'confine' a release to what was intended when it was given for a particular purpose and it was understood by the parties to be limited to that purpose. ${ }^{80}$ Wilde B framed the matter in terms of ignorance: 'a release shall not be construed as applying to something of which the party executing it was ignorant', stating that this was a doctrine of equity that now had to be applied in a court of law. ${ }^{81}$ While Martin B's formulation is perhaps narrower, the majority affirmed the modern rule.

The reasoning in the judgments is almost as thin as the digest just given. Sheehan notes that contemporary comment suggested it was treated as a case of interpretation. ${ }^{82}$ But by going further back through the cases discussed above, one can find sufficient evidence supporting the proposition that there were clearly two elements to it: interpretation and contemplation. One can also see that the court did not take cognisance that it had muddled together two separate lines of authority. In a kind of fusion of the rules of law and equity - more than 20 years before the Judicature Acts - it

\footnotetext{
${ }^{71}$ Administration of Justice Act 1841 (5 Vict c 5), s 1.

${ }^{72}(1843) 11 \mathrm{M} \& \mathrm{~W} 84$ at 91.

${ }^{73}$ (17 \& 18 Vict c 125), ss 83-86.

${ }^{74}$ Evidence Act 1843 (6 \& 7 Vict c 85), s 1: only as to the defendant's credit at this point.

${ }^{75}$ (9 \& 10 Vict c 95), s 83.

${ }^{76}$ (14 \& 15 Vict c 99), s 2.

${ }^{77}(1861) 6 \mathrm{H} \& \mathrm{~N} 337$.

${ }^{78}$ As Lord Hoffmann put it in BCCI $v$ Ali, above n 9, at [38].

${ }^{79}$ Lyall $v$ Edwards (1861) $6 \mathrm{H} \& \mathrm{~N} 337$ at 344.

${ }^{80} \mathrm{Ibid}$, at 347.

${ }^{81}$ Ibid, at 347.

${ }^{82}$ Sheehan, above n 29.
} 
combined two doctrines with two distinct conceptual bases, one of restrictive interpretation and another of rescission for mistake.

No doubt the paucity of law reporting, particularly the absence of reported equitable interpretation cases, did not help. It would not have been as clear as it could have been that some of the equitable cases were of the interpretation of documentary evidence, a broadly objective process in line with common law interpretation, and some were of the determination of subjective belief as to the knowledge of one's rights for the purposes of rescission for mistake. The same goes for the paucity of theorisation in the judgments and contemporary treatises, the latter being much more descriptive than the analytical texts of today. The result, however, is clear. The modern rule of releases had been born, ironically, out of mistake in both senses.

The rule was confirmed, albeit briefly, by the House of Lords in London and South Western Railway Co $v$ Blackmore. ${ }^{83}$ There is just one more case, Moore $v$ Weston, ${ }^{84}$ before fusion and the end of the split court system. None of the English cases from this point up until Ali are particularly illuminating of principle, though. ${ }^{85}$

\section{The objective approach: no space for the contemplation limb}

\section{(a) The beginnings of the objective approach}

It is not a function of this paper to critique the rise of the objective approach in contract law or the retreat of equity from contract. It is therefore enough to set out only the briefest sketch in order to show how objective interpretation would struggle to accommodate the contemplation limb of the rule of releases if it ceased to exist as a separate doctrine.

The tendency of equity to interfere with contracts justified by broad ideas of fairness or good faith has already been noted. This tendency ceased in the nineteenth century. The relevant driving force of this change, it seems, was the rise of the will theory, meaning the courts would not mend bad bargains; their task was simply to hold the parties to what they had agreed. ${ }^{86}$ Anti-evasion, therefore, was a significant concern. A party could not escape liability simply by claiming he had not agreed, was mistaken about something, or had been unduly pressured. ${ }^{87}$ Of this shift, Atiyah wrote that '[d]uress and mistake were whittled away in the nineteenth century as defences to actions on executory contracts till virtually nothing was left of them, ${ }^{88}$

We see the rise of objectivism in what is probably the most fundamental doctrinal expression of the will theory, namely the objective theory of contract. Cases prior to roughly 1850 have been taken to be authority that the court was looking to what the parties actually, subjectively thought, when deciding what to hold them to. ${ }^{89}$ By the time we come to Smith $v$ Hughes (1871), the modern approach had almost been reached; it mattered not what the party actually thought (the subjective approach), but what the party appeared to think (the objective approach). ${ }^{90}$ The irrelevance of subjective intention was emphasised; contracting parties should be able to rely on what is objectively apparent, in accordance with a stronger version of the will theory. A sharp distinction between subjective and objective states of mind is still apparent today and can be seen in the recent judgment of the Court of Appeal in Four Seasons. ${ }^{91}$

\footnotetext{
${ }^{83}(1870) 4$ LR HL 610 at 623.

${ }^{84}$ (1872) 25 LT 542. See the criticism of this case in John Grant (1954) 91 CLR 112 at 128, 133.

${ }^{85}$ Turner $v$ Turner (1880) 14 Ch D 829; Ex p Good, Re Armitage (1877) 5 Ch D 46; Ecclesiastical Comrs for England $v$ North Eastern Railway Co (1877) 4 Ch D 845; Cloutte v Storey [1911] 1 Ch 18; Re Perkins [1898] 2 Ch 182; Richmond v Savill [1926] 2 KB 530; Arrale v Costain Civil Engineering Ltd [1976] 1 Lloyd's Rep 98.

${ }^{86}$ See eg D Friedmann 'The objective principle and mistake and involuntariness in contract and restitution' (2003) 119 LQR 68; Atiyah, above n 48, pp 434-438.

${ }^{87}$ Bell v Lever Bros [1932] AC 161 at 224.

${ }^{88}$ Atiyah, above n 48 , p 435.

${ }^{89}$ See AWB Simpson 'Innovation in nineteenth century contract law' (1975) 91 LQR 247 at 265-269.

${ }^{90}(1871) 6$ LR QB 597 at 607.

${ }^{91}$ [2019] EWCA Civ 1361.
} 
Of course, this post-dates Lyall $v$ Edwards somewhat. ${ }^{92}$ Both the general retreat of equity and the rise of objectivism cut against the rule of releases. The broad justification for the contemplation limb of the rule of releases appears to be the old equitable concerns. While this is not terribly clear from the old judgments (which go so far as expressing concerns with the releasor's ignorance), ${ }^{93}$ in the cases of BCCI v Ali (in the Court of Appeal) ${ }^{94}$ and John Grant ${ }^{95}$ the courts rationalised its existence due to the need to prevent unconscionability, which in this context can only mean fairness or good faith. The post-Smith $v$ Hughes objective approach also militates against the contemplation limb, suggesting that the releasor should be held to the plain words of what she promised. From the post-Tudor cases discussed above it can be seen that while there were some contextual elements in the intentionbased common law version of the rule of releases, they do not appear to reach beyond classes of claim and a time cut-off, let alone further still into matter the parties merely subjectively contemplated.

It follows that the contemplation limb would have remained an equitable rule at this time, since it could not then have been rationalised as part of objective common law interpretation. In this way, it was a unique rule sui generis even in the late nineteenth century.

\section{(b) Recent changes to the objective approach}

In the twentieth century the courts began to take a contextual approach more generally and look to the wider circumstances of the parties to interpret their documents and utterances rather than focusing on the literal text of the words. ${ }^{96}$ This built on the objective foundations laid in the nineteenth century. The new objective approach has regard to the 'matrix of fact', anything reasonably available to the parties that would affect how that reasonable observer would interpret the utterance. The touchstone case is Investors Compensation Scheme Ltd $v$ West Bromwich Building Society, where Lord Hoffmann, the champion of this approach, gave the leading speech. ${ }^{97}$

This approach is less likely to defeat the parties' intentions if a phrase was infelicitously expressed because the courts would take a commonsense approach to construing it. In fact, Lord Hoffmann drove the approach much further. He argued that 'there is not, so to speak, a limit to the amount of red ink or verbal rearrangement or correction which the court is allowed'. ${ }^{98}$ This increase in flexibility started a further movement to subsume other doctrines of contract law into this process.

Two attractions drove this movement. The first is justifying such doctrines. If contractual rights and obligations arise consensually, then any binding rules of law that can be characterised as arising from the intentions of the parties as merely construed from their words, that liability can be justified as merely upholding their wills. It would then be right to allow them to get on with their business as they agreed it without unjustified interference. ${ }^{99}$

The second is to redefine those doctrines. Casting them into the process of objective interpretation means it is the boundaries of interpretation, applied to the particular circumstances of the original doctrine, that govern the requirements and the remedy. This yields three aspects. The first is that the doctrines become more flexible within that constraint. The second is that any parts that cannot be characterised as what the parties intended (as construed objectively) fall out of the doctrines and cease to be law. The third is that the remedy must be a normal contractual remedy. This can be briefly illustrated with some doctrines which Lord Hoffmann attempted to shift into interpretation.

\footnotetext{
${ }^{92}(1861) 6 \mathrm{H} \& \mathrm{~N} 337$.

${ }^{93}$ Eg Cann v Cann (1721) 1 P Wms 723 at 727; Farewell v Coker (1726) 2 Jac \& W 192 at 192; Naylor v Winch (1824) 1 Sim \& St 555 at 560; Lyall $v$ Edwards (1861) $6 \mathrm{H} \& \mathrm{~N} 337$ at 348.

${ }^{94}$ [2000] 3 All ER 51 at [33], [80].

${ }^{95}(1954) 91$ CLR 112 at $125,130$.

${ }^{96}$ See eg G McMeel 'Interpretation and mistake in contract law' (2006) Lloyd's Maritime and Commercial Law Quarterly 49; PS Atiyah Essays on Contract (Oxford: Clarendon, Repr edn, 2001) essay 9.

${ }^{97}[1998] 1$ WLR 896.

${ }^{98}$ Chartbrook Ltd v Persimmon Homes Ltd [2009] UKHL 38, [2009] 1 AC 1101 at [25].

${ }^{99}$ See above n 86.
} 
Consequently we saw the matter of remoteness of loss characterised by Lord Hoffmann as an exercise in interpretation in Transfield Shipping Inc v Mercator Shipping Inc (The Achilleas). ${ }^{100}$ Whether a contract-breaker was responsible for the consequences of the breach (and thus if they were not too remote) depended on whether there had been an assumption of responsibility for those consequences as determined from the words of the contract and not only determined from the more rigid traditional rules. ${ }^{101}$ This yielded a different outcome. Lord Hoffmann made a similar argument for terms implied in fact in A-G of Belize $v$ Belize Telecom Ltd: 'the central idea [is] that the proposed implied term must spell out what the contract actually means'. ${ }^{102}$ The traditional inflexible rules were merely ways in which to express that central idea, but the doctrine was ultimately wider and it would be easier to imply terms by looking to the true central idea. ${ }^{103}$ The Court of Appeal followed his lead in applying the objective method to common mistake rectification in Daventry District Council v Daventry \& District Housing Ltd. ${ }^{104}$

Coming to the immediate matter of the rule of releases, it is plain to see how one might accommodate the rule of releases in this expansive approach to interpretation. Its outcome - that the release is upheld on terms rather than avoided altogether - is apparently desirable, given the courts' policy imperatives and matches the outcome of interpretation. Moreover, the flexibility of the Lord Hoffmann-era approach to objective interpretation may well have accommodated the contemplation limb of the rule of releases. The background is that only certain claims were contemplated and the release should be interpreted with this in mind; Lord Hoffmann made this clear in $\mathrm{Ali}^{105}$

Although he did not press this point, since he was disagreeing with the outcome, one might continue with Lord Hoffmann's other observations about objective interpretation. Since the amount of 'red ink' is not limited, even if the release were so general it made it absolutely clear that every possible liability was included, this can be overridden if there is sufficient context to indicate a limitation to the general words. Arguably there is. Clearly one can interpret the release with the relevant context that the parties had contemplated only the liabilities they were aware of. Then, with a little help from an appeal to general business practice as context, as we see in Lord Nicholls' speech in $A l i,{ }^{106}$ one may interpret the release as being limited to contemplated liabilities, in line with that business practice. This, remarkably, would then allow the process of objective interpretation to take into consideration the parties' subjective thoughts. Finally, there could be one of two possible sub-outcomes, determined by a proper consideration of the context. Either the parties intended to release only the liabilities contemplated, paying off particular claims; or they intended to buy peace, releasing all possible liabilities.

However, even if one accepts that this ostensibly objective process can indeed reliably have regard to the parties' subjective thoughts, the uncertainty of such an expansive approach to contractual interpretation and the concomitant stream of appeals put paid to this wider role for interpretation. The conflicting views of Lord Hoffmann and the other Law Lords in Ali as to the final decision are a case in point. It seems, according to the recent Supreme Court authority of Arnold $v$ Britton, that unambiguous terms will be interpreted according to what they say, even if the result is uncommercial and not what the parties subjectively intended. ${ }^{107}$ Comments about an unlimited amount of 'red ink' are conspicuous by their absence. While the courts are still willing to construe away errors in the dates

\footnotetext{
${ }^{100}$ [2008] UKHL 48, [2009] 1 AC 61.

${ }^{101}$ Hadley v Baxendale (1854) 9 Exch 341; Victoria Laundry (Windsor) Ld v Newman Industries Ld [1949] 2 KB 528; Koufos v C Czarnikow Ltd (The Heron II) [1969] 1 AC 350. See eg JW Carter and W Courtney 'Unexpressed intention and contract construction' (2017) 37 Oxford Journal of Legal Studies 326.

${ }^{102}$ [2009] UKPC 10, [2009] 1 WLR 1988 at [27].

${ }^{103}$ Ibid, at [27].

${ }^{104}$ [2011] EWCA Civ 1153, [2012] 1 WLR 1333 following Chartbrook [2009] UKHL 38.

${ }^{105}$ [2001] UKHL 8 at [37].

${ }^{106}$ Ibid, at [28].

${ }^{107}$ [2015] UKSC 36 particularly at [109], [19]; see PS Davies 'Bad bargains' (2019) 72 Current Legal Problems 253 at 267. See also eg D McLauchlan 'Some fallacies concerning the law of contract interpretation' (2017) Lloyd's Maritime and Commercial Law Quarterly 506 at 507: 'a more conservative approach'.
} 
written in break notices, these cases feature very strong contextual elements, namely when that break is expected to be. ${ }^{108}$ This feature will be absent from most general release cases, because what a party contemplates is subjective and there will usually not be any independent, objective evidence of it. As for remoteness and implied terms, the signs are now that The Achilleas will only apply to exceptional cases ${ }^{109}$ and the old restrictive rules will apply to terms implied in fact. ${ }^{110}$ Four Seasons has supplanted Daventry by putting subjective elements back into rectification. ${ }^{11}$ The role for interpretation has been drawn back and these doctrines, insofar as they might have been subsumed, have been expelled from it.

It is therefore readily arguably that the contemplation limb of the rule has also been expelled from the process of interpretation on the basis that the latter's flexibility and reach has been reined in. If even Lord Hoffmann thought the Ali release was taking the doctrine of interpretation too far and his approach has been curtailed, it is hard to see many taking it further than he. That suggests that the contemplation limb, in its present or in a reduced form, must find a home in a separate doctrine.

That leaves the question of what would happen if there is no home for it and we are left only with contractual interpretation to house the rule of releases. That would probably return the rule to the state where it only covered cases where the recitals limited the general words and future claims would not be included. ${ }^{112}$ Then, the release in Hospital Products would have covered the claim. It is probable that the release in Ali would have done so too, since on Lord Hoffmann's view that the rule was one of only construction, excluding unknown claims would have made the release 'nonsensical'. ${ }^{113}$ Alternatively, one might suppose that that the rule, in this form, might stretch to claims which simply did not exist at the time the release was concluded on the basis that they could not possibly have been intended. But not only does this go against the powerful inference that if one intends to buy peace one really means it, it would also be an extremely niche exception.

This would, at least, leave the application of the law very certain, since the courts would not have to consider difficult and perhaps contradictory extrinsic evidence, a time-consuming and costly process. But, particularly in cases like Hospital Products, it would be very hard on the innocent, duped claimant. We therefore consider, in the next two sections, full and reduced forms of the contemplation limb respectively and how they might deal with this situation.

\section{The conceptual coherence of the rule: a hybrid rule sui generis?}

What might save a broader rule of releases is if it is coherent and meets the courts' policy objectives. There is still a tendency to fit the principles of contract law into 'hermetically sealed subcompartments', as McMeel puts it, ${ }^{114}$ which, one must suppose, is to keep the law coherent. As for the courts' objectives, at least the majority of four of the Law Lords and all the members of the Court of Appeal in Ali thought the rule, functionally, was good law. Scott V-C and Chadwick LJ said it would be 'unconscionable' to allow BCCI to rely on the release given the parties had not

\footnotetext{
${ }^{108}$ Pease v Carter [2020] EWCA Civ 175, [2020] 1 WLR 1459; Mannai Investment Co Ltd v Eagle Star Life Assurance Co Ltd [1997] AC 749.

${ }^{109}$ Siemens Building Technologies FE Ltd v Supershield Ltd [2010] EWCA Civ 7, [2010] 2 All ER (Comm) 1185.

${ }^{110}$ MঔS v BNP [2015] UKSC 72; The Moorcock (1889) 14 PD 64; Shirlaw v Southern Foundries (1926), Ltd [1939] 2 KB 206.

${ }^{111}$ Four Seasons [2019] EWCA Civ 1361. See eg PS Davies 'Rectification rectified' (2020) 79 Cambridge Law Journal 8.

${ }^{112}$ There is a side-issue in the 'exclusionary rule' that pre-contractual negotiations are not admissible for claims to interpret a contract: ICS [1998] 1 WLR 896 at 913. This would often exclude evidence of what the parties thought they were releasing. Although in BCCI $v A l i$, above $\mathrm{n}$ 9, at [31] Lord Nicholls kept open the possibility that an exception to the rule might be created, the admission of such evidence would probably not avail the releasor who used plain general words that purported to release all claims or the relevant class of claims.

${ }^{113} B C C I v A l i$, above $\mathrm{n} 9$, at [47]; see above, text to $\mathrm{n} 18$.

${ }^{114}$ G McMeel "Equitable" mistake repudiated: the demise of Solle v Butcher?' (2002) Lloyd's Maritime and Commercial Law Quarterly 449 at 449; see also C Hare 'Inequitable mistake' (2003) 62 Cambridge Law Journal 29.
} 
contemplated the stigma damages claim, ${ }^{115}$ so it does appear to come down largely to the matter of coherence. A rule sui generis that has utility and does not trample over other principles of contract law warrants keeping.

Lack of coherence is probably what did for the doctrine of equitable rescission for mistake. The Court of Appeal's judgment in The Great Peace, where it gave the quietus to the equitable version of rescission for mistake, can be characterised as the tidying up of an unruly doctrine of dubious provenance. This was essentially for two reasons: it was impossible to distinguish between the fundamental mistake required for rescission at common law and the mistake required for rescission in equity; and the precedents relied on to support it were indeed dubious in that they did not disclose a coherent doctrine of mistake. That left at least the common law doctrine of common mistake to do the necessary work. ${ }^{116}$ These grounds apply at least in part to the rule of releases. While its historic precedents are sound, they were muddled up in Lyall $v$ Edwards. The question is then whether this muddling resulted in coherent, or incoherent law.

The rule did not have an auspicious start. It is a 'fusion fallacy' to take the Judicature Acts to have fused the substantive rules of the common law and equity. Rejecting this proposition, it was held as early as 1883 that fusion was only procedural. ${ }^{117}$ Yet we see in Lyall $v$ Edwards a fusion fallacy even before fusion itself was completed.

Worse still, the general injunction against fusion fallacies is augmented by a specific reason for not mixing these particular principles. It is not only that its differing sources possibly could, but that they actually did, rely on different and incompatible conceptual bases, namely rescission for mistake and upholding the contract on a restricted interpretation. In general, a rule straddling two opposing conceptual bases like these will be hopelessly incoherent and fail utterly when faced with circumstances that engage both.

Remarkably, however, the peculiar fact pattern of compromises means that this does not happen. The modern rule of releases happily accommodates both conceptual bases because of the limited nature of its remedy, namely upholding only the parts of a general release that the parties intended and had contemplated. This may be shown by characterising a general release as having mistaken and unmistaken parts. Restraining it to what was intended and contemplated and upholding that in effect severs these parts. The unmistaken part (claims both contemplated and intended to be released) is upheld, and the mistaken part (claims not contemplated, for which intention to release them is vitiated) is not. It does not matter that the words of the release do not express this cleavage. As for the mistaken part, there is no great functional difference in the outcome whether the remedy is (partial) rescission or not upholding that part of the contract. ${ }^{118}$ Either way, the uncontemplated claims are not released.

This does, however, go somewhat against the schema of English contract law. It relies on a notional partial rescission, which does not exist in 'true' standalone form. Rescission is 'an all or nothing process', according to the Court of Appeal in TSB Bank Plc $v$ Camfield. ${ }^{119}$ There, a principal debtor misrepresented to his surety that her liability was limited to $£ 15,000$, but this was not so. Granting 'full' rescission and relieving her of all liability, the Court refused to uphold the surety's liability up to the truth of the representation and thus enforce that for which she was not mistaken. Here we see a new case where sealing off the boundaries of each doctrinal compartment precisely has proven to be more important than flexibility. But it is only a notional partial rescission in a release case, and this may be considered tolerable by the courts. It is because of this, and because the rule straddles two conceptual

\footnotetext{
${ }^{115}$ [2000] 3 All ER 51 at [33], [80].

${ }^{116}$ [2002] EWCA Civ 1407 at [100]; see Pitt $v$ Holt [2013] UKSC 26 at [115].

${ }^{117}$ Britain $v$ Rossiter (1883) 11 QBD 123.

${ }^{118}$ One might quibble over the precise shape of the remedies. For instance, absent statutory intervention, consequential losses are not available in rescission since the remedy is restitutionary, and there is at most an indemnity: Whittington $v$ Seale-Hayne (1900) 82 LT 49, 16 TLR 181, 44 Sol Jo 229.

${ }^{119}$ [1995] 1 WLR 430 at 436.
} 
bases, I claim it is sui generis. Moreover, since it functions without conflict and incoherence and has utility, it is worth keeping.

One should note that there may well be cases where rescission is the appropriate remedy for a mistake over a release. If the mistake really is so fundamental that consent is nullified, ${ }^{120}$ then setting aside the release in entirety - including the unmistaken part - is justified. This will be when the parties really do need to reconsider the whole matter and the compromise breaks down in its entirety. Here, no notional severance is possible and the two conceptual bases cannot be reconciled on the facts.

\section{Equitable subjectivism in modern contract law: a non-disclosure rule?}

If that is too much to bear, given the proper role the courts ascribe to subjectivism, a reduced version of the contemplation limb may be appropriate. That reduced form is a non-disclosure rule, where if the releasor makes a mistake by purporting to release an uncontemplated claim, and the other party knows of the mistake (or contributes to it by mispresenting its non-existence), then then the release will not extend to that uncontemplated claim. This may be derived from the judicial pronouncements of the role of subjectivism in contract law by the Court of Appeal in Four Seasons.

While there are exceptions to the principle that the doctrine of misrepresentation does not ordinarily hold non-disclosure to be actionable, ${ }^{121}$ those the usual ones are not applicable here. Contracts of employment are not fiduciary, ${ }^{122}$ nor are most agreements to settle contracts uberrimae fidei. ${ }^{123}$ However, the present rule of releases can be characterised as importing a de facto rule of disclosure, ${ }^{124}$ something the facts and outcome of Hospital Products illustrate well. ${ }^{125}$ Moreover, there is already a peculiar exception for the case of releases within family arrangements, in which the non-disclosure of a relevant known fact is indeed actionable. ${ }^{126}$ For these arrangements, contracts of release have been described by the courts as contracts uberrimae fidei. ${ }^{127}$ Indeed, Lord Hoffmann mooted taking this approach to all contracts of release in $A l i .{ }^{128}$

Lord Hoffmann did not develop the point since it was not in issue on the facts of Ali. This can be done now. The Court of Appeal's recent judgment in the rectification case of Four Seasons gives a good indication of the role of subjective knowledge and where the requirement for good faith justifies interfering with contracts. Indeed, the contemplation limb of the rule of releases and rectification are both founded on mistake; the latter is said to require (amongst other things) a 'common assumption as to the existence of a state of affairs. ${ }^{129}$ In cases of releases that would be the non-existence of a claim or a class of claims. They are then at least close cousins with similar justifications.

The Court of Appeal held that a subjective approach to whether a party was mistaken was appropriate for unilateral mistake; the same was appropriate for common mistake when there was no preexisting contract. ${ }^{130}$ For unilateral mistake, the justification was that it would be contrary to the principle of good faith to enforce the contract unrectified if the party seeking to enforce it knew of the other's mistake. ${ }^{131}$ For common mistake absent a pre-existing contract, the justification is essentially the same.

\footnotetext{
${ }^{120}$ Applying Bell $v$ Lever Bros [1932] AC 161 at 217.

${ }^{121}$ Turner v Green [1895] 2 Ch 205; Chitty, above n 54, para 7-018.

${ }^{122}$ Unless special features are present: University of Nottingham v Fishel [2000] ICR 1462; Ranson v Customer Systems plc [2012] EWCA Civ 841, [2012] IRLR 769.

${ }^{123}$ Silver Queen Maritime Ltd v Persia Petroleum Services plc [2010] EWHC 2867 (QB) at [130].

${ }^{124}$ As is done in Chitty, above n 54, para 7-158.

${ }^{125}$ Above, text to $\mathrm{n} 27$.

${ }^{126}$ BCCI v Ali, above n 9, at [69]. See J Cartwright Misrepresentation, Mistake and Non-Disclosure (London: Sweet \& Maxwell, 4th edn, 2017) at para 17-35; Chitty, above n 54, para 7-174.

${ }^{127}$ Tennent $v$ Tennents (1870) LR 2 Sc 6 at 10.

${ }^{128}$ Above, text to $\mathrm{n} 25$.

${ }^{129}$ The Great Peace [2002] EWCA Civ 1407 at [76].

${ }^{130}$ Four Seasons [2019] EWCA Civ 1361 at [105], [147], [176].

${ }^{131}$ Ibid, at [55].
} 
It rests on the equitable doctrine that a party will not be allowed to enforce the terms of a written contract, objectively ascertained, when to do so is against conscience because it is inconsistent with what both parties in fact intended (and mutually understood each other to intend) those terms to be when the document was executed. This basis for rectification is entirely concerned with the parties' subjective states of mind. The underlying moral principle can be characterised $\ldots$ as being that persons who make a contract have to observe certain standards of good faith. ${ }^{132}$

Nonetheless, for common mistake where there is no pre-existing enforceable contract, it is necessary that there be an 'outward expression of accord' of the parties' true but misrecorded intentions to warrant rectification. ${ }^{133}$ This is shown by the words emphasised in that quotation, which, oddly enough, were placed in parentheses despite their importance. It is necessary that the party trying to rely on the unrectified contract know of the error of the other party to the contract to engage the doctrine. So much is brought out explicitly elsewhere in the judgment:

In the case of common mistake it is inequitable for a party to the contract to seek to apply the contract inconsistently with what that party knew to be the common intention of the parties when the written contract was executed. ${ }^{134}$

Thus the Court of Appeal's discussion suggests that for both unilateral and common mistake knowledge of the other party's mistake is essential for rectification. For releases this suggests that, at a minimum, it is appropriate to restrain a release when the other party knows the releasor is mistaken as to the extent of the claims that would be released, or, to put it another way, when the non-releasing party makes a suggestio falsi or suppressio veri of that fact. However, it does not go so far as to suggest that the law must restrain a release where the releasor is ignorant of some claims in the class but has not expressed that ignorance in some way and the other party does not know of that ignorance.

On the other hand, one should not read too much into these arguments. First, it simply does not follow logically that just because it is inequitable to enforce a contract according to its plain written terms when the mistake is known, it is equitable to enforce it when the mistake is unknown. There may be other factors. Secondly, the comments were made in the context of rectification, which is a different remedy. Rectification corrects mistakes as to what is recorded, not what was intended. It does not correct a misapprehension as to the effect or consequences of a transaction, unlike the rule of releases. ${ }^{135}$ It is therefore easier to derive a minimum than a maximum from Four Seasons. Certainly the case does not exclude the existence of the contemplation limb.

We can, therefore, say with some confidence that the reasoning in Four Seasons demands the rule of releases have, at a minimum, a non-disclosure limb if it loses the contemplation limb, but equally it does not rule out the contemplation limb. Such a rule would mean that the release in Hospital Products would not have covered the contentious circumstances because of the suppressio veri. Conversely, it would mean that the releases BCCI $v$ Ali and Lyall $v$ Edwards would indeed have covered the contentious circumstances because there was no misrepresentation nor suppression of the truth. This would be a substantial retrenchment of the rule of releases. But it would not go so far as the unattractive option of abolishing the contemplation limb without replacing it with anything. It thus seems - as a minimum - to be what is required. But ultimately the matter is open to the courts.

\footnotetext{
${ }^{132}$ Ibid, at [146] (emphasis added).

${ }^{133}$ Ibid, at [67] ff.

${ }^{134}$ Ibid, at [105]; see also at [147].

${ }^{135}$ Gibbon v Mitchell [1990] 1 WLR 1304 at 1309; Joscelyne $v$ Nissen [1970] 2 QB 86 at 97 commenting on Frederick E Rose (London) Ltd v William H Pim Jnr \& Co Ltd [1953] 2 QB 450 (the 'horsebeans case'). The rationalisation of Rose $v$ Pym in Four Seasons [2019] EWCA Civ 1361 at [70] did not concern this point but instead the scenario 'where parties had deliberately chosen words but were mistaken about their meaning'. See also the remarks in Smith v Hughes (1871) 6 LR QB 597 at 609.
} 
It is worth mentioning one last matter before concluding. The remedy obtained in the family cases has apparently been rescission rather than upholding the contract on terms. ${ }^{136}$ While rescission may be desirable in at least the worst cases of sharp practice because the whole agreement needs to be revisited, there may be cases where it is desirable to uphold the part relating to what was not mistaken. But one can simply put the outcome in the family cases down to them falling in the former category rather than because of the existence of a rigid rule that the remedy for non-disclosure is always rescission. Particularly for divorce settlements, non-disclosure will often require rescission of the whole agreement, because it will not be possible to sever the unmistaken part of the agreement and the settlement will have to be completely restructured.

\section{Conclusion}

That is the remarkable story of the modern rule of releases, which, perhaps by pure chance, emerged as a coherent rule sui generis, straddling the conceptual bases of both consent and vitiation of consent. Being confined to a particular type of contract, this ostensibly incoherent combination actually functions well, even if it does not fit into the any of the familiar doctrinal compartments of the law of contract such as mistake, misrepresentation, rectification or interpretation. Perhaps more importantly, it fulfils an important function. The other doctrines alone simply cannot do its job. Misrepresentation does not take into account non-disclosure or ignorance, rectification is too distant to apply and interpretation alone would take away the contemplation limb without replacing it with anything to deal with cases of sharp practice.

This may well be enough to save the rule of releases from the courts' reforming tendency to tidy up and compartmentalise the doctrines of contract law. This of course depends on how much the courts value it, and whether the more restricted non-disclosure version offers, in their opinion, a better option. As argued above, that is the bare minimum; without it, cases of sharp practice could proceed with impunity.

If one is to try to divine which the courts would prefer, one can put the matter of doctrine aside and look broadly to the judgments of Ali. The Court of Appeal's judgment suggests there is still a place for limited equitable intervention in contract in the form of the present rule of releases. Furthermore, at least a majority of four of the Law Lords in Ali thought the rule was, functionally, good law. There does, therefore, seem to be considerable support for keeping it as is.

\footnotetext{
${ }^{136}$ In Gordon v Gordon (1819) 3 Swans 400 the remedy is declared clearly.
}

Cite this article: Whayman D (2021). The modern rule of releases. Legal Studies 41, 493-510. https://doi.org/10.1017/ lst.2021.18 